\title{
BAudelAiRe: ANTíTESES E REVOLUÇÃO
}

Olgária Matos

* (FOUCAULT, Michel, Archivio Foucault, 3, 19751985. Torino: Feltrinelli, 1998: 231.)
"Desaparecimento dos vestígios do pecado original", a modernidade não é desencantamento psíquico e da cultura, mas o tempo que nela reina soberano: o tédio. Em "O Quarto Duplo", Baudelaire destitui o sujeito de suas prerrogativas clássicas de autor do sentido do mundo, quando a consciência garantia voz de comando sobre toda Natureza e sobre os homens. Personalizando o Tempo, ao grafá-lo em maiúscula, o poeta desfaz a harmonia interior, a intimidade do quarto, os objetos tornados parciais e autônomos com respeito uns aos outros, replicando o que se passa com o próprio Eu que perde permanência, constância e identidade. Assim, cabe ao Sujeito exercer os "cuidados de si", abjurando a tutela da religião e da ciência, renunciando à ambição de realizar uma "verdade do Eu": "O homem moderno, para Baudelaire, não é alguém que vai em busca de si mesmo, de seus segredos e de sua esquiva verdade; é alguém que procura inventar-se a si mesmo. Esta modernidade não libera 'o homem em seu próprio ser', mas o constrange a enfrentar a tarefa de se produzir a si mesmo." $\mathrm{Na}$ modernidade, produzir-se a si mesmo significa movimentar-se em meio a um mundo em huis clos - o tempo espacializado dos cronômetros e relógios. Associado ao recinto fechado do quarto, o tédio é a intrusão violenta - em um refúgio que deveria ser acolhedor, tranqüilizante e protetor - do "princípio de realidade" moderno: a universalização fetichista do dinheiro que domina todas as esferas da vida e o espírito protocolar e burocrático que o acompanha. Por isso, a "infame concubina", o "meirinho", o "oficial do cartório” são sua perfeita tradução.

Em "O Quarto Duplo", a enumeração das partes do Eu e dos objetos nesse intérieur ${ }^{1}$ perverso, desfaz o cosmos e, acentuando

\footnotetext{
${ }^{1}$ No arquivo "O Intérieur, o Rastro" de suas Passagens, Walter Benjamin analisa os interiores burgueses sob Napoleão III, interiores saturados de enfeites, de dourados, espelhos, paredes forradas de tecidos adamascados com desenhos florais, tapetes, móveis em forma de naves ou cadeiras góticas, de onde o "burguês via o mundo" com o ilusório sentimento de segurança no mundo do capital: "o intérieur do século XIX. O espaço se disfarça, assumindo a roupagem dos estados de ânimo como um ser sedutor.O pequeno-burguês, satisfeito consigo mesmo, deve experimentar algo da sensação de que no aposento ao lado pudessem
} 
a desordem, introduz nele o caos. O que se desenrola na interioridade - do quarto, do Sujeito - é o duplo do mundo externo, cujo horror é o de um "universo morno num horizonte plúmbeo", com a "fria crueldade de um sol que congela.", como em "De Profundis Clamavi”: "...por seis meses um morno sol dissolve a bruma,/ E durante outros seis a noite cobre o solo; / É um país bem mais nu do que o desnudo pólo/ - Nem bestas, nem regatos, nem floresta alguma!/ Não há no mundo horror que comparar se possa/ À luz perversa desse sol que o gelo acossa/ $\mathrm{E}$ à noite imensa que no velho Caos se abriu; Invejo a sorte do animal mais vil,/ Capaz de mergulhar num sono que o enregela,/ Enquanto o Dédalo do tempo se enovela." $\mathrm{O}$ tédio é deserto demoníaco e caos.

Para tratar das transformaçóes sociais e culturais do capitalismo e da cidade de Paris, Baudelaire as entende segundo uma "teologia do inferno", a modernidade sendo a "queda de Deus". Não se trata de cisões de dois mundos - céu e inferno - pois esta separação é conseqüência da cultura dualista da qual Deus é o criador, cultura que polariza bem e mal, matéria e espírito, corpo e alma, Deus e Satã. Neste sentido, Baudelaire anota: "A Teologia. O que é a queda? Se é a unidade que se tornou dualidade, foi Deus quem caiu. Em outros termos, não seria a criação a queda de Deus?" Colocando-se acima da cultura dualista, responsável pelo tédio que aflige o mundo moderno, o Poeta e o "dândi revolucionário" surgem por "decreto das potências supremas", sendo seu dever denunciar a falsidade dos valores sobre os quais essa vida se funda. Operando por antíteses, Baudelaire propõe: "a lei dos contrastes [...]

ter ocorrido tanto a coroação do imperador Carlos Magno como o assassinato de Henrique IV[...]. Ao final, as coisas são apenas manequins e mesmo os grandes movimentos da história universal são apenas roupagens sob as quais elas trocam olhares de conivência com o nada, com o trivial e o banal. Semelhante niilismo é o cerne do aconchego burguês; um estado de espírito que se condensa na embriaguez do haxixe em satisfaçóes satânicas, em saber satânico, em quietude satânica, mas que assim revela como o intérieur dessa época é, ele mesmo, um estimulante da embriaguez e do sonho.Aliás, esse estado de espírito implica uma aversão contra o espaço aberto, por assim dizer uraniano, que lança uma nova luz sobre a extravagante arte decorativa dos espaços interiores da época.Viver dentro deles era como ter se enredado numa teia de aranha espessa, urdida por nós mesmos, na quakl os acontecimentos do mundo ficam suspensos, esparsos, como corpos de insetos ressecados.Esta é a toca que não queremos abandonar BENJAMIN, Walter. Passagens. Organização da edição brasileira de Willi Bolle. Colaboração de Olgária Matos. Trad. de Irene Aron e Cleonice Paes Barreto. Belo Horizonte: Editora UFMG; São Paulo: Imprensa Oficial do Estado de São Paulo, 2006: 251).
"(BAUDELAIRE, Charles. "As Flores do Mal". Trad. Ivan Junqueira. Em Poesia e Prosa. Org. Ivo Barroso. Rio de Janeiro: Nova Aguilar, 1995: 127-128.)

"(Cf. BAudelaire, C. “Mon coeur mis à nu". Em Oeuvres complètes. Bibliothèque de la Pléiade. Paris: Gallimard, 1975, 2 vol.: I, 688.) 
-(Cf. BAudelaire, C. "Conseils aux jeunes littérateurs". Em Ibid.: II, 19.)

-(Cf. BAUDELAIRE, C. "Mon coeur mis à nu". Op. cit.: I, 682.).

$\cdot(: I, 703$.

(Cf. KOYRÉ, Alexandre. Do Mundo fechado ao Universo Infinito. Rio de Janeiro: Forense Universitária, 1979.)

(Cf. Aristóteles, Opere, Física, III. Roma-Bari: Laterza, 1987.) governa a ordem moral e a ordem natural (physique)", por isso há, no homem, "duas postulaçôes simultâneas", "uma na direção de Deus, outra na de Satã." tórios, "o horror da vida e o êxtase da vida", sendo que esta é "sonho e consciência", "spleen e ideal". Na senda de Baudelaire, Benjamin reconhece no capitalismo triunfante um torpor mítico que se abateu sobre o século, o Capital do qual Paris é a capital, é sonho em estado de vigília e, para compreendê-lo, Benjamin reúne o cenário político seiscentista de seu Drama Barroco Alemão do Século XVII ao das arcadas de Paris das Passagens, e indica seu ponto de encontro: "comum a ambos, o tema: teologia do inferno. Alegoria, publicidade, tipos: mártir, tirano-prostituta, especulador". Mundo dos duplos invertidos - o tirano que é mártir, o mártir, tirano, a prostituta é especulador, o explorado, explorador. Universo dos paradoxos baudelairianos, à modernidade falta um "princípio de razão suficiente", segundo a fórmula leibniziana que tudo tem fundamento, "nihil est sine ratione".

Com efeito, entre os séculos XVI e XVII, o Tempo moderno significou o fim do cosmos fechado grego e da transcendência medieval, com o advento do universo infinito. Assim, a physis grega que possuía suas próprias razões imanentes de vir a ser e se transformar, de crescer e desaparecer, era o princípio governado pela "medida prudente e sábia”. A representação antiga de um cosmos finito fazia da natureza norma e limite, a harmonia em que residem leis de funcionamento do mundo e do homem. Ordem estruturante e perfeita, a physis não concorre com os humanos, sua sacralidade preservada por desconhecerem qualquer desejo de ultrapassamento da permanência imutável das coisas. $\mathrm{O}$ infinito, ao contrário da "bela Totalidade", era o ápeiron, o "indefinido", o inacabado. $\mathrm{Na}$ Física, por exemplo, Aristóteles observava ser o infinito imperfeito; o finito o terminado, o acabado, o completo. ${ }^{*}$ Deste modo, o que as filosofias do progresso denominaram civilizações tradicionais refere-se a sua defesa, através de um tempo circular, necessário, com respeito à história. Quanto ao tempo meta-histórico da Idade Média, os acontecimentos se inscreviam na história da salvação, e, por isso, consistiu em um período litúrgico, ao qual importa o que perdura e não o que passa. Se a compreensão religiosa grega e a escatológica cristã dos fins últimos da vida e do universo - em que são limitados os horizontes de expectativa, o futuro vinculando-se ao passado - não previnem essas sociedades de disfun- 
ções e conflitos, elas não apresentam, porém, um mal-estar próprio à modernidade: "o tédio e o vazio de sentido não parecem ter sido um problema maior para essas sociedades." $2^{*} \mathrm{O}$ tédio é contemporâneo da filosofia do progresso, do pensamento que baniu milagres da Bíblia, mas também, em consequiência das transformações culturais e da visão de mundo mecanicista de estilo cartesiano, desvalorizou as coisas criadas, silenciando a natura loquax, instituindo o reino de objetos mortos e regras arbitrárias em um mundo sem esperança de salvação. A modernidade, domínio das mercadorias e do capital, estabeleceu uma Erstaz da fé, os milagres morais do processo histórico.

Tomando o traumatismo da revolução proletária de $1848 \mathrm{em}$ Paris e a repressão de Napoleão III, a modernidade evoca crueldades cometidas e tormentos sofridos, no contexto das terríveis circunstâncias de vida que reinavam em Paris e na França: "Paris, o inferno dos anjos, o paraíso dos demônios." "As condições de trabalho e a descrição dos massacres dos insurretos fazem de Dante uma presença infalível, a metáfora do inferno ampliando o lugar antes circunscrito à existência operária em geral. E, depois de junho, as aproximaçôes com o Terror da Revolução de 1789 e com a "noite de São Bartolomeu dos operários parisienses" foram correntes. Referindo-se à Paris de Napoleão III e à de Haussmann, Benjamin cita Paul-Ernest de Rattier: "A verdadeira Paris é naturalmente uma cidade escura, lamacenta, mal cheirosa, confinada em suas ruas estreitas..., um formigueiro de becos, de ruas sem saída, de alamedas misteriosas, de labirintos que levam você até a casa do diabo; uma cidade em que os tetos pontiagudos de casas sombrias se reúnem perto das nuvens, disputando com você o pouco de azul que o céu nórdico dá de esmola à grande capital. A verdadeira Paris é cheia de pátios de milagres, dormitórios a três centavos por noite, de seres inimagináveis e fantasmagorias humanas... Ali, numa nuvem de vapor de amoníaco... e em camas que não foram arrumadas desde a criação do mundo, repousam, lado a lado, centenas e milhares de saltimbancos, vendedores de fósforos, tocadores de acordeão,

\footnotetext{
${ }^{2}$ Embora presente ao longo da história como akedia antiga, acedia medieval, melancolia na Renascença, o tédio e a monotonia como fenômenos sociais são característicos do mundo moderno, do sujeito privado da objetividade da Natureza dos antigos e da transcendência medieval. cf. MATOS, O., "Aufklärung na Metrópole: Paris e a Via Láctea”. Em: BENJAMIN, W. Passagens. Op. cit. e LARUE, Anne. L'Autre Mélancolie: Acedia ou les chambres de l'esprit. Paris: Hermann, 2001.
}

(SVENDSEN, Lars. Petitie Philosohie de l'ennui. Trad. de Hélène Hervieu. Paris: Fayard, 1999: 228, nota 66.$)$

(HEINE, Heinrich, citado por OEHLER, Dolf. $O$ velho mundo desce aos infernos. São Paulo, Companhia das Letras, 1999: 44.) 
- (BENJAMIN, W. "As ruas de Paris". Passagens. Op. cit.: 564-565.)

$\cdot$ (OEHLER, D. O velho mundo desce aos infernos. Op. cit.: 41)

(Cf. OEHLER, D. O veIho mundo desce aos infernos. Op. cit.: 80, e o poema "Abel et Caïn", entre outros. BAUDELAIRE, C. "Les Fleurs du Mal". Em Oeuvres complètes. Op. cit.: I, 122-123.) corcundas, cegos, mancos; anões e aleijados, homens com o nariz devorado em brigas; homens-borracha, palhaços envelhecidos, engolidores de espadas, malabaristas que equilibram um pau-de-sebo entre os dentes... Crianças de quatro pernas, gigantes bascos ou outros tipos, o pequeno Polegar em sua vigésima encarnação [...]; esqueletos vivos, homens transparentes feitos de luz..., cuja voz debilitada pode ser escutada por um ouvido atento...; orangotangos com inteligência humana; monstros que falam francês."*

A iminência de sublevações se expressa em fórmulas ameaçadoras, em panfletos indicando que assim que o povo saísse de seu inferno, seria o inferno dos afortunados: "o século XIX tende a pensar o movimento histórico com categorias teológico-morais e uma de suas idéias fixas é o Mal.”* Mesmo Marx e Engels, que evitavam moralizar, partilharam o maniqueísmo, Marx apresentando os "plebeus" como mártires de uma burguesia ensandecida, de sua guarda móvel - "sanguinários cães da ordem.”. Por um lado, o egoísmo dos dominantes, a injustiça social, a "depravação dos privilégios"; de outro, a inveja dos pobres, nas palavras de Thiers, ou "a inquietude de espírito", nas de Tocqueville. Porque Paris - em 1789, 1830, 1848 e 1871 - inaugura a era do Capital e das barricadas, ela é o arquétipo da modernidade, é o tempo do inferno, das revoluções e das contra-revoluções, e a redenção, antes teológica, se fará agora nos eventos temporais e pelo surgimento de uma nova personagem: o herói revolucionário.

Esse período assiste à oposição entre irmãos inimigos, Caim e Abel, à construção do martírio, em favor de Caim, com referência a Robespierre, "esse Caim da fraternidade". Temos aqui os antecedentes da noção de luta de classes e a justificativa moral da violência nos termos de Caim, pois, embora tenha cometido um assassinato, ele foi injustamente desfavorecido por Deus. A partir de então, Marx compreenderá a cisão da sociedade em campos irreconciliáveis ou, entre capital e trabalho. $\mathrm{O}$ ideal da fraternidade, presente nos frontões de fevereiro de 1848, é assim denunciado por Marx: "a fraternité, a fraternidade das classes antagônicas, uma explorada pela outra, esta fraternité, proclamada em fevereiro, inscrita em letras garrafais nos frontões de Paris, sobre cada prisão, sobre cada caserna - a sua expressão verdadeira, autêntica, prosaica é a guerra civil, a guerra civil em sua forma mais terrível, a guerra entre o trabalho e o capital. Essa fraternidade flamejava diante de todas as janelas de Paris na noite de 25 de junho, quando a Pa- 
ris da burguesia iluminava-se, ao passo que a Paris do proletariado ardia, sangrava, gemia." ${ }^{*}$ Esse período a que o historiador Maurice Agulhon denominou "aprendizado da República", polarizou, como proclamado por Marx, o antagonismo entre as classes, circunscritas em papéis estritamente econômicos, a moral como moral de uma classe, as leis como leis de uma classe, segundo a oposição amigo/ inimigo. Citando Marx, que chama a revolução de "nosso bom amigo, nosso Robin Hood, a velha toupeira que sabe trabalhar tão rapidamente sob a terra", Benjamin anota: "Na Idade Média havia na Alemanha um tribunal secreto a Femgericht, para vingar os desmandos dos poderosos. Quando se via um sinal vermelho em uma casa, aquilo significava que seu proprietário caíra nas garras do Femgericht. Hoje há em todas as casas da Europa uma misteriosa cruz vermelha. A própria história é o juiz - e quem executa a sentença é o proletariado."”

As lutas operárias de fevereiro - a conquista dos "três oitos"(" 8 horas de trabalho, oito horas de descanso, oito horas de sono", bem como o "direito ao trabalho") - resultaram, no mês de junho, em sangue, de que a literatura da época, em particular a de Baudelaire, testemunha o horror. A repressão de junho de 1848 conclui-se na inércia do proletariado e da burguesia, no "despotismo do tédio". Em seu poema "Ao Leitor", expondo-se aos demônios para melhor apreender suas causas, Baudelaire denuncia o sonho de destruição do mundo: "Na almofada do Mal é Satã Trismegisto/ Quem docemente nosso espírito consola,/ [...] É o diabo que nos move e até nos manuseia!/ Dia após dia, para o inferno caminhamos,/ Sem medo algum, dentro da treva que nauseia [...]/ Em nosso crânio um povo de demônios cresce [...]/ Em meio às hienas, às serpentes, aos chacais/ Aos símios, escorpiōes, abutres e panteras, / Aos monstros ululantes e às viscosas feras [...]/ Um há mais feio, mais iníquo,

\footnotetext{
${ }^{3}$ Horkheimer permanece atento às ambigüidades do conceito marxiano de proletariado, "ficção heurística" de Marx: comunidade imaginária, classe inteiramente histórica e ao mesmo tempo fora da história, classe que não é uma classe porque dissolve todas as classes, ser que realiza os destinos de toda a humanidade. (Cf. Dämerun ...). Também Benjamin, afastando-se da letra do pensamento de Marx, aponta algumas dificuldades na conceituação.Em seu arquivo U, das Passagens transcreve uma citação que diferencia Saint-Simon e Marx: "O primeiro amplia de modo mais abrangente possível o número dos explorados, incluindo entre eles até os empresários, uma vez que estes pagam juros a seus credores. Marx, ao contrário, inclui na burguesia todos aqueles que de alguma forma são exploradores, ainda que estes também sejam vítimas de exploração" (BENJAMIN, W. "SaintSimon, Ferrovias". Passagens. Op. cit.: 621).
}

* (Marx, K. Die neue Reinishen Zeitung, MEGA, vol V. Berlin: Akademie Verlag, 2001.)

* (Cf. MARX, Karl, apud BENJAMIN, W. "Movimento Social". Em Passagens. Op. cit.: 771.)

* (Cf. OEHLER, D. "Morte. Fim do velho mundo". $O$ velho mundo desce aos infernos. Op. cit.: 92.) 
- (BAUDELAIRE, C. "Salão de 1859". Trad. Suely Cassal. Em Poesia e Prosa. Op. cit.: 821.).

(BAUDELAIRE, C. "Salão de $1846 "$. Trad. Suely Cassal. Em Poesia e Prosa. Op. cit.: 711.$)$

(BAUDELAIRE, C, citado por BENJAMIN, W. Passagens. Op cit.: 353. Cf. ainda "As Ruas de Paris". Passagens. Op. cit.: 560.) mais imundo/ Sem grandes gestos ou sequer lançar um grito,/ Da Terra, por prazer, faria um só detrito/ E num bocejo imenso engoliria o mundo./ É o Tédio![...] Tu o conheces, leitor, aos monstros delicado;/ - Hipócrita leitor, meu igual, meu irmão.”

A natureza mortífera do tédio das Flores do Mal resulta no dandismo da indiferença dos Projéteis face à degradação que a modernidade atesta em seu imobilismo: "Confesso que o que mais me mortifica nesses espetáculos [Baudelaire analisa aqui uma das pinturas de batalha de Horace Vernet] não é a profusão de ferimentos, a abundância hedionda de membros mutilados, mas sobretudo a imobilidade na violência e a espantosa e fria máscara de um furor paralisado." Antes disso, no "Salão" de 1846, o poeta anotara, pensando também em seu padrasto, o general Aupick, que Vernet, por ser um militar que pretende praticar a pintura, só consegue borrar pinceladas militares: "O sr. Horace Vernet é um militar que faz pintura. - Eu odeio esta arte improvisada ao rufar do tambor, estas telas borradas num galope, esta pintura fabricada com tiros de pistola, assim como odeio o exército e as forças armadas, e tudo que carrega armas barulhentas para um lugar pacífico. Essa imensa popularidade que, aliás, não durará mais tempo que a guerra, e diminuirá à medida que os povos tiverem outras alegrias - essa popularidade, repito, esta vox populi, vox Dei, é para mim uma opressão." Essa “imobilidade no mal" é a do tempo dominado pelo tédio, um dos avatares do inferno, sentimento de prisão no espaço cristalizado e em um tempo estagnado, como no fragmento "Sintomas de ruínas": "Fendas, rachaduras. Umidade proveniente de um reservatório situado perto do céu. - Como alertar as pessoas, as nações? Uma torre. - Labirinto. Nunca consegui sair. [...]. Calculo, mentalmente, [...] se uma tão prodigiosa massa, de pedras, mármores, estátuas, paredes que vão se chocar umas contra as outras, serão infectadas por essa multidão de cérebros, de carnes humanas e de ossadas trituradas. Vejo coisas tão terríveis em sonho que gostaria algumas vezes de não mais dormir." ${ }^{*}$

"Eternidade negativa", esse tempo é doentio, é um labirinto cheio de cadáveres. Ruas, arcadas e escadarias constituem uma Babel espacial, em que o "assombro do espaço é o assombro da privação do espaço". Refletindo sobre o labirinto baudelairiano, Benja-

\footnotetext{
${ }^{4}$ Georges Poulet, referindo-se a este fragmento de Baudelaire, indica ser ele inspirado nos Carceri de Piranese. Cf. "Piranèse et les poètes romantiques français". Em Trois Essais de Mythologie Romantique. Paris: José Corti, 1966.
} 
min contrapõe a "rua" ao antigo "caminho": "Ambos são completamente diferentes no que diz respeito a sua natureza mitológica. O caminho traz consigo os terrores da errância. Um reflexo deles deve ter recaído sobre os líderes dos povos nômades. Ainda hoje, nas voltas e decisões incalculáveis dos caminhos, todo caminhante solitário sente o poder que as antigas diretrizes exerciam sobre as hordas errantes. Entretanto, quem percorre uma rua parece não precisar de uma mão que o aconselhe e guie. Não é na errância que o homem sucumbe à rua; ele é submetido, ao contrário, pela faixa de asfalto, monótona e fascinante, que se desenrola diante dele. A síntese desses dois terrores, no entanto - a errância monótona - é representada pelo labirinto", prisão em que a infinidade do espaço coincide com seu fechamento.

Fantasmagoria do espaço e de privação do espaço, o labirinto identifica-se com a fonte de todas as perversidades e, também, de ânsia por novidades, no labirinto do consumo. A produção em série das mercadorias, a monotonia da multiplicação ao infinito do Mesmo, o medo pânico da deriva entre prateleiras e vitrines das galerias e lojas de departamento, dissimulam-se nas pequenas variações nos protótipos de maneira a dissimular o sentimento de angústia e induzir à compra, para manter o circuito em funcionamento. Esse período é o do crescimento do proletariado e do capital especulativo, ${ }^{5}$ a produção de mercadorias em série afetando o devir temporal. Por isso Benjamin afirma que, na modernidade, mesmo os acontecimentos históricos se repetem como artigos em série no labirinto do consumo. ${ }^{6}$

Período "cinzento pintado de cinzento" - drama farsesco em que tudo deve mudar para permanecer igual -, Marx o concebe, no Dezoito Brumário, como repetição histórica: "história sem acontecimentos; desenvolvimentos cuja única força motriz parece ser o calendário, cansativo pela repetição constante das mesmas tensões e das mesmas distensões". O capitalismo realiza revoluções permanentes no modo de produção, arquiva formas de vida e de traba-

\footnotetext{
${ }^{5}$ Em "Paris, Capital do Século XIX", Benjamin escreve que, sob Luís Felipe, Paris tornou-se a "sala de visita onde os banqueiros fazem seus negócios". Sob Luís Felipe, Paris vive "as mais belas horas da especulação".

${ }^{6}$ No arquivo N das Passagens, em que Benjamin procede à crítica da noção capitalista de progresso, a situação mortífera do tédio é apresentada a partir da hipótese astronômica da "eternidade pelos astros" de Blanqui, o "Eterno Retorno" das forças cósmicas de Nietzsche, conceitos ampliados no "eterno retorno do sempre igual” (das Immergleiche). Cf. BENJAMIN, W. Passagens. Op. cit.: 499-530.
} 
- (Cf. BAUDELAIRE, C. "Salão de 1859", e também "Volúpia", em As Flores do Mal)

- (POULET, Georges. Études sur le tempos humain. Paris: Plon, 1950: 365.) lho, desenraizando os homens de seus hábitos e valores e criando Langeweile e Ennui. ${ }^{7}$ Embora a modernidade seja, para Baudelaire, tédio - "infortúnio medíocre" que derrota todo desejo de ação -, este não aniquila, no spleenético, "anseios espirituais", "ambições tenebrosamente recalcadas", "Volúpia”. Neste sentido, Baudelaire se refere a "Mulheres de Argel" de Delacroix, apreendendo nelas a vida vegetativa no harém, vida de espera e tédio. "São "mulheres doentes", "doentias", cuja beleza interior provém desta "tensão dos nervos", de sua "dor moral".

O tédio é, conforme ele diz, um sentimento aristocrático que tenciona spleen e ideal, realidade prosaica e transcendência utópica, passado (spleen) e futuro (ideal). Aqui o pascalianismo de Baudelaire: "do caráter duplo e contraditório da natureza humana", escreve Poulet, "destaca-se, pois, no pensamento de Baudelaire, a concepção de uma beleza que, também ela, tem uma dupla natureza e um duplo rosto: uma natureza permanente e uma transitória, uma face de grandeza e uma de miséria. E em um mesmo movimento, descobre-se a possibilidade de viver em um tempo que não seria nem o tempo da eternidade dos estados paradisíacos, nem o tempo infeliz dos estados infernais; mas um tempo duplo que, na infelicidade, conteria a promessa de felicidade, que do feio faria surgir a beleza". Já a monotonia caracteriza as massas. Inapelavelmente patológica, ela é tempo imóvel que não passa. Dominados por ela, não se é capaz de reconhecer ou criar valores. Tempo esvaziado de significações, é tão monótono quanto o gesto repetitivo do trabalhador junto à máquina. $\mathrm{O}$ capitalismo contemporâneo herda da filosofia e da literatura do século XIX a exclamação de Gautier: "antes a barbárie que o tédio". A cultura contemporâ-

\footnotetext{
${ }^{7}$ A monotonia que impregna a sociedade de massa coincide com o "esquecimento da política” e da descrença com respeito a projetos coletivos, seu esvaziamento resulta em "realismo político" e "decisionismo", ideologias que são "pseudo-teorias do real", com o que "os espíritos fortes se entregam ao culto da facticidade, esta deusa cruel, acompanhada por um assistente também cruel, a decisão, se se reconhece que a essência da decisão é de focalizar uma única opção e deixar morrer outras alternativas". (Cf. SLOTERDJIK, Peter. Ecumes - Sphères III. Paris: Maren Sell, 2005: 618). Atesta-se a crise da democracia representativa, por exemplo, na ineficácia da Lei ou em sua inoperância, como nos casos de abusos de poder (práticas militares e policiais, entre outras), "improbidades administrativas"!, etc. (Cf. também MATOS, O. "Aufklärung na Metrópole: Paris e a Via Láctea”. Op. cit.)
} 
nea combinou os dois: "Guerras, guerras sem nenhum interesse/ O tédio das guerras de cem anos." ${ }^{*}$

O tempo da monotonia recebe algo dos anacoretas dos desertos de Alexandria e da acídia medieval que, a partir do século IV, caracteriza um estado moral de indiferença, desânimo e apatia do coração, temidos como sinais do demônio. O demônio do meiodia (daemon meridianus), de todos, o mais ardiloso, é o que surpreende monges em plena luz diurna, dando-lhes a impressão de um sol imóvel e de um dia insuportavelmente longo. Diferenciando-se da acídia - pecado mortal porque o demônio faz com que o religioso, em seu recolhimento, venha a recusar o lugar em que se encontra e a vida que tem - o tédio e a monotonia não constituem apenas um fenômeno subjetivo e individual, mas da história social moderna e da cultura. Se, em fevereiro de 1848, Baudelaire encontrava-se nas barricadas militantes, depois de junho, seguiram-se destruição e apatia da sociedade. Acentuando a duplicidade antitética de suas Flores do Mal, Baudelaire, como notou Benjamin, "via a Revolução dos dois lados", dentro e fora da burguesia. Apoiado na visão pascaliana do homo duplex, afasta-se da glorificação do proletariado e da luta entre as classes. "Deslocando as litanias do "povo sempre sofredor" para as de Satã, o "senhor dos disfarces", aquele que tem "um duplo rosto", "figura da marginalidade", "deus deposto", "príncipe do exílio", "Deus traído pela sorte”, "Príncipe e protetor dos exilados e proscritos", Baudelaire concebe a reversibilidade das forças: "Ormuz e Arimã, vós sois o mesmo". Carrasco e vítima confundidos, entre o povo e o tirano há sempre uma "furiosa reciprocidade". Em meio à carnificina das forças policiais defensoras das classes abastadas, os vencedores também têm seus supliciados, seus deputados, generais e bispos "que tombaram em nome da ordem". No arquivo "Movimento Social”, Benjamin

\footnotetext{
${ }^{8}$ A literatura, de Dostoievski a Musil, e a filosofia, de Schopenhauer e Kierkegaard, Camus e Cioran, passando por Benjamin e Heidegger, tematizam o tédio na cultura capitalista, a da produção de mercadorias e de não-senso, de "pobreza da experiência". Como Heidegger, para quem o capitalismo, o bolchevismo e o americanismo são suas expressões: o presente prosaico é o vazio, o tédio, a ambigüidade e a pobreza de verdadeiros acontecimentos. Cf. Ser e Tempo e as análises heideggerianas sobre a inautenticidade, o tédio e a situação existencial daqueles exilados à margem de qualquer sentido na história, jogados na pura facticidade, expostos na nebulosa esfera da mundaneidade. O homem moderno, o do progresso, "erigiu em Deus a imagem de sua própria mediocridade". Cf Os Conceitos Fundamentais da metafisica: Mundo, finitude, solidão.
}

" (POUND, Ezra. The Cantos-Revised collected edition. London: Faber and Faber, 1975: 23.) 
-(BENJAMIN, W. Passagens. Op. cit: 743.)

(BAUDELAIRE, C. Lettres à sa Mère. Paris, Calmann-Lévy, 1932: 278.) cita um episódio da insurreição de junho de 1848: "viam-se mulheres jogando óleo fervente ou água escaldante nos soldados, aos berros e aos gritos. Em alguns pontos davam aos insurgentes uma aguardente misturada com diversos ingredientes, que os excitava até a loucura... Algumas mulheres cortavam os órgãos genitais de vários soldados da guarda aprisionados; sabe-se que um insurgente, vestido com roupas femininas, decapitou vários oficiais prisioneiros... viam-se cabeças de soldados espetadas em lanças plantadas sobre as barricadas [...]. Muitos insurgentes fizeram uso de balas que não podiam mais ser retiradas dos ferimentos, porque tinham um arame que as atravessava de um lado a outro. Por detrás de várias barricadas havia bombas de pressão que projetavam ácido sulfúrico contra os soldados que atacavam. Seria impossível relatar todas as atrocidades diabólicas praticadas por ambos os lados." Século das "festas sangrentas das revoluções", Baudelaire se diz "physiquement dépolitiqué". Assim, no poema em prosa de 1864, que torna ultrapassadas as Litanias de Satã de 1853, Satã responde ao interlocutor que lhe pede "notícias de Deus", "com uma indiferença nuançada por uma certa tristeza": "nós nos cumprimentamos quando nos encontramos, mas como dois velhos cavalheiros em quem uma polidez inata não conseguiria apagar completamente a lembrança de antigos rancores.”

Essa Paris prosaica, dominada pelo tédio, é a da degradação temporal e de seus valores, como em $O$ Cisne, cujos versos falam de uma Andrômaca troiana e da "imensa majestade" de sua dor passada, agora convertida na silhueta de uma "negra tísica", expressão baudelairiana da modernidade. ${ }^{9}$ E na "Negação de São Pedro", desenvolve a "metafísica do provocação", em um mundo em que "a ação não é irmã do sonho". "Espanquemos os Pobres", "O Mau Vidraceiro", "O Bolo" exprimem menos sua " histeria” que satanismo e dandismo, a maneira baudelairiana de escapar ao satus quo, ao realismo político: "se alguma vez recuperar o vigor e a energia que já possuî", escreve Baudelaire a sua mãe, "então desabafarei minha cólera através de livros horripilantes. Quero incitar toda a raça humana contra mim. Seria uma volúpia que me compensaria por tudo." Recusando a empatia filantrópica e patriarcal

${ }^{9} \mathrm{O}$ recurso baudelairiano aos modelos da Antigüidade Clássica (Vênus, Pomona) e aos religiosos medievais revela que o poeta-filósofo desiste do sonho de uma simultaneidade ou sincretismo entre o passado e o presente, como em "A Musa doente", em que se misturam o sangue cristão da musa, que circularia como os "numerosos sons das sílabas antigas". 
com os misérables, Baudelaire descarta também a filosofia do progresso, advertindo seus burgueses que não menosprezem os pobres, superestimando-se a si próprios: "mesmo quando Baudelaire se faz simbolicamente carrasco, permanece, sob o disfarce do satanismo, é claro, um homem das Luzes." "10* "Senhor das antíteses"11 e dos múltiplos sentidos, as Flores do Mal pertencem a uma época para a qual " flores" eram o "bem”. Desalojando o bem como virtude espiritual ou cívica, o Mal é o tédio, simultaneamente, mal moral e doença crônica.

A "nova Paris", a da batalha de junho e do estado de sítio consecutivo, a Paris de 1851, "foi com freqüência descrita como uma necrópole [...], viva só na aparência."* Essa paisagem de coisas mortas e tempo estagnado aparece em "Quarto de Casal", ${ }^{12}$ onde reina o Tempo mecânico e obsedante dos ponteiros dos relógios, seus minutos e segundos: "o Tempo agora reina como soberano [...] e retornou todo o seu cortejo demoníaco de Lembranças, Pesares, de Espasmos, de Terrores, de Angústias, de Pesadelos, de Cóleras e de Neuroses." "A modernidade é "queda satânica" que conduz a intermináveis recaídas de Sísifo, é fluxo de instantes estáticos e seqüências mórbidas, é sono letárgico e retorno da violência mítica: "O tédio", escreve Benjamin, "é o lado externo dos acontecimen-

${ }^{10}$ Messages disparus de Job, antes do versos "Pleurez sur l'araignée..."

${ }^{11} \mathrm{O}$ "espírito de contradição" é, em Baudelaire, "crítica do presente". Comentando as "energias teóricas" da prosa de Baudelaire, Benjamin escreve: "O mais das vezes Baudelaire expõe opiniōes apoditicamente. Discutir não é a sua seara. Ele o evita mesmo quando as evidentes contradições em teses que adota sucessivamente exigiriam um debate. O "Salão de 1846", ele o dedicou 'aos burgueses' [...]. Mais tarde, por exemplo em suas investidas contra a escola do bon-sens, encontra para a 'honnête' burguesia e para o notário - a figura do respeito no meio burguês - os traços da boêmia mais raivosa. Por volta de 1850, declara que a arte não deve ser separada da utilidade; alguns anos depois defende l'art pour l'art." (BENJAMIN, W. Charles Baudelaire, um lírico no auge do capitalismo. Trad. José Carlos Barbosa e Hemerson Alves Batista. São Paulo: Brasiliense, 1991: 10.) O paradoxo opera, na obra de Baudelaire, como um anti-sistema, pois este é, por definição, o regime das classificações de diferenças assim codificadas. Tampouco aceita o "indiferenciado", o "sem-sistema" pois consiste em uma "sedução satânica." (Cf. "Exposição Universal de 1855").

${ }^{12}$ Leda Tenório da Motta traduz o fragmento "Chambre Double" de Spleen de Paris por "Quarto de Casal” e Aurélio Buarque de Holanda Ferreira escolhe "Quarto Duplo" em Poesia e Prosa,op cit. Ambas são igualmente possíveis, embora "quarto duplo", nos hotéis, não indique necessariamente de "casal". Leda T. da Motta, por ocasião do colóquio, sugere "conjugado" para "chambre double", que resguarda a idéia da proximidade e evoca o "cônjuge" impossível, as lesbianas, as passantes. Para a autora, não convém "quarto duplo" para o poeta das alcovas, dos recônditos secretos e do profundis.
- (Cf. OEHLER, D O velho mundo desce aos infernos. Op. cit.: 189.)

"(OEHLER, D. O velho mundo desce aos infernos. Op. cit.: 101.)

* (BAudelaire, C. "Pequenos Poemas em Prosa". Trad. de Aurélio Buarque Ferreira". Em Poesia e Prosa. Op cit.: 282.) 
- (BENJAMIN, W. "O Tédio, Eterno retorno". Passagens. Op. cit.: 146.$)$

-(BENJAMIN, W. Passagens. Op. cit.: 350.)

(MOTTA, Leda Tenório. Proust: a violência sutil do riso. São Paulo: Perspectiva, 2007: 143.) tos inconscientes", "é o retorno do reprimido: o Mal. O homo duplex em um mundo em que "diminuem os rastros do pecado original", que "vai acabar" pelo "aviltamento dos corações", bem como as carnificinas, tudo inviabiliza aceitar a idéia de que os movimentos sociais podem ser dramáticos mas, no fim das contas, seguem adiante porque a história tem sentido e finalidade. $\mathrm{O}$ diagnóstico baudelairiano do moderno é satânico, não é marxista, é o dos duplos em tensão: "Tu que, mesmo ao leproso e ao pária, se preciso,/ Ensinas por amor o amor do Paraíso.” É assim que Baudelaire, segundo Desjardins, aliou a sensibilidade do Marquês de Sade às doutrinas de Jansenius." ${ }^{*}$ Baudelaire, como um Pascal, entende que a natureza inteira participa do pecado original, da mesma forma que Sade convida, por náusea e derrisão, a rivalizar com ela. E como Jansenius, "quer se jogar por terra como o culpado que suplica a graça." De onde atitudes contraditórias, mártir e carrasco em cada homem, vítima e sacrificador. Por isso, Baudelaire não adere ao ideário marxista, evolucionista e positivista do progresso, e, em "Espanquemos os Pobres!", não se limita a dar ouvidos às insinuaçôes de seu demônios internos; transforma-as em atos imaginários, resguardando-se de acrescer à revolta dos pobres um discurso ideológico - o que levaria Brecht a considerar que Baudelaire tinha "abjurado suas idéias revolucionárias" e "apunhalado o movimento operário pelas costas". Baudelaire, o "parteiro dândi do movimento revolucionário dos pobres", não adere ao comunismo de tipo marxista, a ele preferindo o satanismo e os caricaturistas modernos, esses "reveladores de sintomas morais" e artesãos do riso. E isso porque "o artista só é artista sob a condição de não ignorar nenhum fenômeno de sua dupla natureza": "entre a miséria e a grandeza de sua condição, ao mesmo tempo humilhada e altiva, o caricaturista da alma humana trabalha com desenhos violentos e idéias sutis." ${ }^{*}$ Cultor dos contrastes violentos, Baudelaire reconhece neles a duplicidade e a vertigem do homem decaído, esse "rei de um país chuvoso" em uma terra de exílio. ${ }^{13}$

\footnotetext{
${ }^{13} \mathrm{O}$ sentimento de um mal ontológico, de uma falha da natureza, inerente à condição do homem mortal, é compensado pela imaginação e pelo pensamento. Como uma medicina da alma que vence o despotismo de ampulhetas e relógios, Baudelaire anota que "a Arte é longa, o Tempo é curto."
} 


\section{Olgária Matos}

Olgária Matos é professora titular de Filosofia da Universidade de São Paulo. É doutora em Filosofia pela USP (1985) e tem pós-doutorado pela École des Hautes Études en Sciences Sociales (1993). É autora de Os Arcanos do inteiramente outro (Brasiliense, 1995), $O$ Iluminismo Visionário: Walter Benjamin, leitor de Descartes e Kant (Brasiliense, 1999), Escola de Frankfurt, Luzes e Sombras do Iluminismo (Moderna, 2006, 2a ed.), Discretas esperanças: reflexôes filosóficas sobre o mundo contemporâneo (Nova Alexandria, 2006), entre outros.

\section{Resumo}

O ensaio procura indicar o método baudelairian o das antiteses de coisas e acontecimentos, de tal forma que o maniqueísmo progressista da dialética hegeliano-marxista é substituído pelo homo duplex pascaliano, e o conceito de ação política e arte engajada é reformulado.

\section{Abstract}

The essay attempts to characterize Baudelaire's method of promoting antitheses between things and events, in such a way that the progressive Manichaeism of Hegelian-Marxist dialectics is replaced by the homo duplex of Pascal, leading to a reformulation of the concept of political action and committed art.

\section{Résumé}

L'essai cherche à indiquer la méthode baudelairienne des antithèses des choses et des événements, si bien que le manichéisme progressiste de la dilectique hégéliano-marxiste est remplacé par le homo duplex pascalien et que le concept d'action politique et art engagé est reformulé.
Palavras-chave: Baudelaire; Benjamin; poesia; revolução.
Key words: Baudelaire; Benjamin; poetry; revolution Mots-clés: Baudelaire; Benjamin; poésie; révolution 